Актуальні проблеми української лінгвістики: теорія і практика

\title{
RESOURCES
}

(Vinn) - Vinnytske TTU - hroshei "kury ne kliuiut"? URL: http://svobodaslova.in.ua/news/read/722

(Hryp) - Hryp ta yoho uskladnennia. URL: http://hudorba.pp.ua/2015/05/28/grip-ta-jogo-uskladnennya/

(Iushch) - Yushchenko: Meni sumno vid pryznachennia Shufrycha ministrom. URL: https:/ua.korrespondent.net/ukraine/281349-yushchenkomeni-sumno-vid-priznachennya-shufricha-ministrom

Дата надходження до редакції - 01.10.2018 p.
Дата затвердження редакцісю - 16.11.2018 p.

УДК $81 ` 366+81 ` 367^{\wedge} 225$

DOI: https://doi.org/10.17721/APULTP.2018.37.156-184

Aytan Z. Aliyeva

\section{SEMANTIC AND FUNCTIONAL FEATURES OF TAUROMACHY (BULLFIGHTING) VOCABULARY WITHIN THE FRAMEWORK OF COGNITIVE AND LINGUOCULTUROLOGICAL APPROACHES}

Abstract. The article is dedicated to the investigation and interpretation of semantic and functional features of phraseological expressions and paroemias referring to tauromachy (bullfighting) within the framework of cognitive and linguoculturological approaches. The introduction of relevant examples in the article aims to detect these features. Tauromachy which is called "an art of bullfighting" is an inseparable part of Spanish culture. Corrida (bullfight) has deep historical roots and it is a specific, festive occasion belonging to the Spanish people. It has entered into the national consciousness of Spaniards, developed and reflected in all manifestation forms of their lives. In its turn, it has lead to the linguistic reflection of tauromachy vocabulary in the language. According to their use in the language, tauromachy terms have four levels: words referring to tauromachy which is a special field and used only in the bullfight, tauromachy words with figurative meaning that can be used as a 
methaphora in other fields, tauromachy words used in literature and words referring to tauromachy field used in spoken language.

Linguoculturological approach is a new stage of the study of complex relations between language, thinking and culture within the framework of cognitive linguistics. Linguistic and semantic aspects of cognitivism, that's, mental imaginations of a language speaker are observed more vividly in phraseological expressions and paroemias. In the article we will try to study phraseological expressions and paroemias referring to tauromachy used in the spoken language, that's, the fourth level of the use of tauromachy vocabulary in the language. It is obvious that the phraseological system generalizes language units with extremely great value in terms of understanding the level of national language consciousness of the people. Phraseological expressions and paroemias can be considered precious linguoculturological source, so that daily lifestyle, world outlook, traditions of language speakers are reflected in the phraseological system visually through metaphoric coding. The vocabulary of tauromachy in this field has gone through certain processes and gained new connotative meanings and assists in more concrete, laconic, expressive delivery of the idea being used in the spoken language.

Key words: cognitive linguistics, linguoculturology, tauromachy, phraseological units, paroemias.

Information about author: Aliyeva Aytan Ziyatkhan - candidate for scientific degree in Azerbaijan National academy of sciences; teacher of the department of foreign languages; faculty of translation and cultural studies; Azerbaijan University of languages; Baku, Azerbaijan.

E-mail: aytanaliyeva@yahoo.com.

Алієва A.3.

\section{СЕМАНТИЧНО-ФУНКЦІОНАЛЬНІ ОСОБЛИВОСТІ ЛЕКСИКИ ТАВРОМАХІЇ В КОНТЕКСТІ КОГНІТИВНОГО Й ЛІНГВОКУЛЬТУРОЛОГІЧНОГО ПІДХОДІВ}

Анотація. Стаття присвячена інтерпретації та дослідженню семантично-функціональних особливостей фразеологічних одиниць $i$ паремій, пов'язаних із лексикою тавромахії, в контексті когнітивного та лінгвокультурологічного підходів. Тавромахія, відома як 
Актуальні проблеми української лінгвістики: теорія і практика

"мистецтво кориди", є невід'ємною частиною іспанської культури. Корида має глибоке історичне коріння $i \in$ особливим святом іспанського народу. Вона увійшла в національну свідомість іспанців, а отже, відбивається в усіх формах їх життя. Це, у свою чергу, призвело до відображення лексики тавромахії в мові. Терміни таврамахії складаються з чотирьох рівнів відповідно до використання в мові: слова стосуються спеціальної галузі тавромахії та використовуються тільки при описі бою биків; образні слова тавромахії, які можуть використовуватися як метафори в інших галузях; слова, використовувані в літературі; слова тавромахії, активно вживані в розмовній мові. Лінгвокультурологічний підхід у контексті когнітивної лінгвістики $\epsilon$ новим етапом $у$ вивченні взаємозв'язку мови, мислення та культури. Лінгвістичні та семантичні аспекти когнітивізму більш широко виявляються у фразеологічних одинииях $i$ пареміях. $У$ статті ми спробуємо дослідити фразеологізми та паремії, що стосуються тавромахії та використовуються в розмовній мові, тобто одинииі четвертого рівня використання лексики тавромахії в мові. Відомо, шчо фразеологічна система - це мовні одиничі, які мають велике значення з погляду розуміння рівня начіональної мовної свідомості людей. Фразеологічні одиниці та паремії можна розглядати як иінні лінгвокультурологічні джерела, оскільки повсякденний спосіб життя, світогляд, традииї мовних носіїв чітко відображені у фразеологічній системі за допомогою метафоричного кодування. Лексика тавромахії в цій галузі набуває нових конотативних значень і використовується в розмовній мові, щцоб допомогти передати ідею та смисли більш точно, лаконічно та виразно.

Ключові слова: когнітивна лінгвістика, лингвокультурологія, тавромахія, фразеологічні одиниці, паремії.

Інформація про автора: Алієва Айтен Зіятхан - дисертант Національної академії наук Азербайджану; викладач кафедри іноземних мов; факультет перекладу та культурології; Азербайджанський Університет мов; Баку, Азербайджан.

Електронна адреса: aytanaliyeva@yahoo.com. 


\title{
СЕМАНТИКО-ФУНКЦИОНАЛЬНЫЕ \\ ОСОБЕННОСТИ ЛЕКСИКИ ТАВРОМАХИИ В КОНТЕКСТЕ КОГНИТИВНОГО И ЛИНГВОКУЛЬТУРОЛОГИЧЕСКОГО ПОДХОДОВ
}

\begin{abstract}
Аннотация. Статья посвящена интерпретации $и$ исследованию семантико-функииональных особенностей
\end{abstract} фразеологических единии и паремий, связанных лексикой тавромахии, в контексте когнитивного и лингвокультурологического подходов. Тавромахия, называемая "искусством корриды", является неотьемлемой частью испанской культуры. Коррида имеет глубокие исторические корни и является особым праздником испанского народа. Она вошла в национальное сознание испанцев, а поэтому отображается во всех формах их жизни. Это, в свою очередь, привело к лингвистическому отражению лексики тавромахии в языке. Терминологическая система таврамахии состоит из четырех уровней в соответствии с использованием в языке: слова, относящиеся $\kappa$ специальной области тавромахии и используемые только в описании боев быков; образные слова тавромахии, которые могут использоваться как метафоры в других областях; слова, используемые в литературе; слова тавромахии, используемые в разговорной речи. Лингвокультурологический подход в контексте когнитивной лингвистики является новым этапом в изучении сложных отношений между языком, мышлением и культурой. Лингвистические и семантические аспекты когнитивизма более широко прослеживаются во фразеологических единицах и паремиях. $B$ статье делается попытка исследования фразеологизмов и паремий, относящихся к тавромахии и используемых в разговорной речи, то есть единии четвертого уровня использования лексики тавромахии в языке. Известно, что фразеологическая система - это языковые единицы, которые имеют большое значение с точки зрения понимания уровня национального языкового сознания людей. Фразеологические единицы $и$ паремии можно рассматривать как ценные лингвокультурологические источники, поскольку повседневный образ жизни, мировоззрение, традиции языковых носителей четко отражень во фразеологической системе посредством метафорического кодирования. Лексика тавромахии в этой области, 
Актуальні проблеми української лінгвістики: теорія і практика

проходя через определенные прочессы, приобретает новые коннотативные значение и используется в разговорном языке, чтобы помочь передать идею и смисль более точно, лаконично $u$ выразительно.

Ключевые слова: когнитивная лингвистика, лингвокультурология, тавромахия, фразеологические единицы, паремии.

Информация об авторе: Алиева Айтен Зиятхан - диссертант Начиональной академии наук Азербайджана; преподаватель кафедрь иностранных языков; факультет перевода и культурологии; Азербайджанский Университет языков; Баку, Азербайджан.

Электронный адрес: aytanaliyeva@yahoo.com.

Cognitive linguistics is a linguistic direction which has found its place in world's linguistic science and continues its active development. According to V.Z. Demyankov and E.S. Kubryakova, cognitive linguistics studies the language as a cognitive mechanism which plays a role in coding and transforming information [12, p. 53-55].

According to Fakhraddin Veysalli, generally, cognition refers all processes of reception, storage, re-use and transmission of information in human brain. These processes occur directly in the background of consciousness. At that time, various systems of knowledge are distinguished. Mechanisms for revealing the features of sensor irritations and their expression in the language occupy a special place in the communication. Cognitive behaviour is based on mental imaginations. Conceptual features and external attributes are activated in these feat and enter into the communication [4, p. 21].

Processes of language use, formation, storage and transmission of information in the language have begun to expand due to the development of the cognitive science. Merely, its formation and continual development show itself as one of features belonging to the linguistics of XX and XXI century.

Cognitive approach to linguistics is a new stage of the study of complex relationship between language and thinking with centuriesold history. E.Y. Balashova characterizing scientific directions in cognitive linguistics, emphasizes two main approaches: linguocognitive and linguoculturological. Linguoculturological approach 
studies the features of national conceptual sphere which have passed from the culture to consciousness [1, p. 55].

Z.D. Popova and I.A. Stern state the following directions within the framework of cognitive linguistics [15, p. 11-12]:

Culturological - introduction of concepts as a cultural element through present different fields of science. Such studies are conducted among scientific fields and they do not have any special relation with linguistics. In this case, language acts only as a source of knowledge about concept (for example, information on the etymology of the word denoting the concept for the description of this concept);

Linguoculturological - introduction of concepts which are an integral part of national linguoculturology as language units of this culture in relation to national values and national features: direction from language to culture, orientation (V.I. Karasik, S.G. Vorkachev, G.G. Slishkin, G.V. Tokarev);

Logical - analysis of concepts with logical methods not directly depending on the form of language (N.D. Arutyunova, R.I. Pavilyonis);

Semantic - cognitive - means for achieving the essence of concepts, study of lexical and grammatical semantics of the language as a means for conceptual modelling from the semantics of the language (E.S. Kubryakova, N.N. Boldirev, E.V. Rakhilina, Z.D. Popova, I.A. Sternin, G.V. Bykova);

Philosophical-semiotic - cognitive bases of signs are studied (A.V. Kravchenko).

According to Wilhelm von Humboldt, the subject of every language, even the poorest and rude language is the language itself and in its turn, it requires deep understanding. Language is not only the manifestation of ideas and thoughts of different peoples as it is accepted, but also it is general spiritual power of peoples which is engraved in sounds in a stunning way and it is the activity of morality that shapes this spiritual power [7, p. 348-349].

E. Benvenist who characterizes language as a system with different structure considers that language shows itself as a product of culture and a factor of formation of cultural codes [23, p. 97]. 
Culture depends on the language and affects the language. The process of interaction between the people's culture and language is an axiom. Rules for language use, principles for the evaluation of people's conversations within the community of speech, speech network, assessment of their social and cultural beliefs, establishment of society and how people interact with each other in society are considered in the process of interaction between the people's culture and language. If we say in Humboldt's words, language and culture are not only two phenomena which are in mutual interaction; they are two social phenomena which have a radical identity.

G.V. Yelizarova talks about three approaches in the determination of culture:

1) according to sociological approach, culture is a general behavior model inherent in human groups (traditions);

2) according to cognitive approach, culture is a collection of thinking style and knowledge accepted by the society and merely, these rule exist for society to operate;

3 ) according to semiotic approach, culture is a system of social meanings encoded with symbols which guarantee for mutual understanding among people belonging to one culture and which is a public expression of commonly accepted ideas [8, p. 14].

We come across with the interaction of culture and language in the book "Linguoculturology" by V.A. Maslow. In the sense of the author, first of all, culture manifests in the language. Language is the true reality of culture, language is able to involve a person in the culture. Language is a point of view of culture fixed to the universe and itself [14, p. 27-28].

V.V. Vorobyov approaches culture differently while explaining its essence: "For us, culture is the organization of human life, special class of public manifestations; it is attention for national identity and first of all, its inner spiritual world; it is the collection of methods of creative activities of the personality in the field of material and moral execution; it is methods of of sharing and using material and spiritual values and achievements in the field of public 
relations that assist in the progressive development of humanity" [6, p. 12-13].

There was a condition to accept postulate arising from the achievements of foreign country scientists in linguistics in the end of $\mathrm{XX}$ century: language is not only related to culture; language develops from the culture and expresses culture. At the same time, language is a means for the formation, development and storage (in the form of text) of culture and its integral part, as real, objective existing works of material and moral culture are created through language. Based on this idea, new science - linguoculturology emerges as a result of centuries.

Linguoculturology as a special field of science was formed in 90 s of XX century. It can be appropriate to note two periods in the development of this science: first period - the period of formation of basis for the development of the science (works by W. Humboldt, A.A. Potebnya, E. Sepir and others) and second period - the period of formation of linguoculturology as a field of independent research. The term "linguoculturology" appeared in the works by V.N. Teliya, V.V. Vorobyov, V.A. Maslow, Y.S. Stepanov, V. Shakleina.

As considered by Y.V. Bromley, everything "from labor tools to domestic tools, traditions, lifestyle of people to science and culture, religion and atheism, spirituality and philosophy" can be attributed to the subject of research of linguoculturology [3, p. 5458].

At present, some directions have been determined in linguoculturology.

1. Linguoculturology of an individual social group and ethnicity in terms of culture in a specific period, that's, the study of a certain linguoculturological condition.

2. Diachronic linguoculturology, that's, the study of changes in linguoculturological condition in a certain period of the ethnicity.

3. Comparative linguoculturology - the study of linguoculturological manifestations of different, but interconnected ethnicities. 
4. Confronting linguoculturology - It starts to develop. At present, there are only some works in this field which the most interesting one among them is the work by M.K. Golovanivskaya entitled "French mentality from the point of view of Russian speaker".

5. Linguoculturological lexicography - is engaged in the creation of linguistic countryism dictionaries [14, p. 27-28].

One fact evidences the urgency of a new course in linguistic that four linguoculturological schools have already been founded in Moscow in a short time (10-15 years of XX century): linguoculturological school of Y.S. Stepanov, linguoculturological school of N.D. Arutyunova, linguoculturological school of V.N. Teliya and her students and linguoculturological school established at Peoples' Friendship University of Russia by V.V. Vorobyov, V.M. Shaklein and others that developed V.G. Kostomarov.

V.A. Maslow's textbook can be considered as one of the famous works. Here, methodological base is given and modern directions of linguoculturological studies in Russia are described. The author emphasizes interdisciplinary nature of linguoculturology and defines it as "a linguistic field that has penetrated into a lively national language and studies material and moral culture manifesting into language processes" or as a field of knowledge that reflects "the results of studies conducted in cultural studies and linguistics, ethnolinguistic and cultural anthropology" in itself [14, p. 9, 30, 32].

According to V.A. Maslow (ibid., p. 35), the purpose of linguoculturology (study of means which the language keeps and demonstrates culture with its units), its duties (how culture takes part in the creation of language concepts or determine whether language speakers/carriers have cultural and language competence), as well as, its apparatus of concept have been formed broadly. The author emphasizes the possibility of using any methods of the study "from interpretation method to psycholinguistic methods".

Theoretical and methodological basis of linguoculturology in modern linguistics are interpreted in the work by V.V. Vorobyov entitled "Linguoculturology: theory and methods" more fully. The 
research work is conducted by the traditions of Humboldtianity: the study of culture reflected in the language is suggested to be conducted on the basis of Sapir-Whorf hypothesis, as well as, terminology applied by L. Weisgerber is used [13, p. 240].

The author states "the interaction between culture and language in usage and the study of this interaction as a single system fully" as a main object of linguoculturology. "National existence forms expressed in the system of language communication of the society and based on its cultural values" - "everything that comprises language picture of the world" acts as the subject of this discipline. [5, p. 32] V.V. Vorobyov determines the main unit of linguoculturological analysis - lingoculturema and defines it as "dialectical unity of linguistic and extralinguistic (concept and subject) composition" (ibid., p. 44-45). Similar issues are resolved in the work by V.V. Krasnykh entitled "Ethno-psycholinguistics and linguoculturology". According to V.V. Krasnykh, the subject of linguoculturology - are units that act as "a channel" which we can enter into cultural-historical layer of mental-lingual complex which have fullness of cultural significance of language and discourse) [10, p.13].

V.I. Karasik accepts linguoculturology as "a science and field of knowledge on the interrelation and interaction of language and culture" and emphasizes its confronting (comparative) nature [9, p. 103, 108, 121]. It notes cultural concept as a main unit of linguoculturology and put forward royalties and "characteristics of concrete and abstract names with content which are necessary for adequately understanding additional information on the culture of certain people, that's, background meanings"( ibid., p. 127-129).

Linguoculturology is defined as a field of science "that studies separate objects of the conceptual picture of the world and understanding by language and public consciousness from the point of view of the object of reflection which one of them is considered to be ethnicity" in the work by Y.I. Sheigal and V.A. Buryakovskaya $[17$, p. 9].

According to A.T. Khrolenko, the determination of mechanisms of interrelation and interaction of language and culture - 
two fundamental phenomenon grounding the human phenomenon must interest linguoculturology [16, pp. 31-32].

According to O.I. Kourova, linguoculturology - is a section of linguistics that studies the interaction of language and culture as a system that reflects linguoculturological values [11, p. 53].

When we say Spain, we immediately remember "bullfighting" (corrida) as a country attribute. Corrida has deep roots and it is a specific festive event belonging to the Spanish people. It has entered into the national consciousness of Spaniards, developed and in its turn, the vocabulary of tauromachy has found its linguistic reflection in the language. The term "tauromachy" (is of Greek origin, meaning: taūros "toro - bull", máchomai "luchar - fight") is defined as "an art of bullfighting" on horseback or on foot. "Bullfighting" which has become an integral part of a Spanish culture has its own rich, lexical base. So, the process from the beggining till the end of the sport can be expressed by language concepts. If we would analyze the vocabulary of tauromachy from the linguoculturological aspect, actualization of terminology referring to tauromachy which is a special field in the spoken language, literature and press texts enables us to determine universal and national - cultural features of this field. Variety of phraseological expressions and paroemias shows the general importance of this vocabulary for Spanish linguoculturology. Lexemes of tauromachy with figurative meaning that can be used as a metaphor in other fields enable to investigate the features of Spanish culture. The description of the reflection of tauromachy in the public mind of the people creates condition to investigate its cognitive signs and describe the psychological state of the people. It should be noted that this vocabulary is exotic extralinguistic lexemes, national, specific words for our language which are mostly given by interpretation, description, explanation and comments in other language.

According to Ramon Pérez de Ayala, "no any field can describe current psychological state of the Spanish people as tauromachy". So, the language of tauromachy is "a philosophical indicator of the Spanish people". 
According to Elias and Dunning's evolutionary theory, spectacular sports reflect the development process of the society: If there is no information on the society in which the level of emotion both in public and personal life is high in comparison with less emotional societies, it is not possible to understand the nature and specific functions of entertainment implemented there. "Por medio de los acontecimientos recreativos, en particular los de la clase mimética, nuestra sociedad cubre la necesidad de experimentar el desbordamiento de las emociones fuertes en público-proporcionando una liberación que no perturba ni pone en peligro el relativo orden de la vida social, cosa que si podría hacer una autentica tensión emocional de tipo serio" [32, p. 85]. Psychology researcher at ICESI University in Colombia, Lina Maria Giraldo Torres, divided the research work entitled "Corridas de toros y movimiento animal: Elaboraciones psicológicas y culturales de la agresividad" into 4 parts. The first part deals about bullfighting, the second part touches upon the theoretical aspects of concepts "agression" and "violence" which directs the course of the research. In addition to congenital biological agression of a person, the type of aggression formed due to social and cultural factors is studied. The third part touches upon the theory of involuntary consciousness based on the theory of Freud's psychoanalytic theory. Analyzes conducted clarifies tauromachy in terms of social phenomenon. Supporters reveal involuntary instincts drown in themselves in tauromachy and as they consider bulls as the reason of these unwanted instincts, they accept aggression towards it normal. The fourth one is a cultural approach. The analysis of cultural components referring to tauromachy is implemented to show that psychological and cultural aspects are complementary. In corrida, "toro" is metaphorized as "man" and bull as "woman". Bull represents unavoidable force, strength, aggressiveness and it is a wild and sensitive being that must be subdued [31, p. 60-66]. Sociologist Tierno Galvan likens bull which is subdued by torero to a woman with rebellious spirit and that obeys to every man and considers that these types of women can be obtained by the methods applied in corrida [37, p. 24]. 
Spaniards use the terms of tauromachy in a metaphoric sense inspired by the participants of this holiday and events occurred in the bullfighting in order to express their problems and concerns without noticing it themselves [18, p. 67]. According to thinker Carlos Gonzalez Alonso, "life is very similar to the bullfighting and therefore, the language therein is deliberately used". We can see it obviously in the examples related to the use of the expressions of tauromachy by writer and historian Carlos Abelia:

En el ruedo se dan los valores de la vida, los mismos que como hombres y mujeres tenemos en nuestra existencia. Se da el miedo y el dominio del mismo: el valor. Se escenifica la solidaridad y la competencia, que no son antagónicas, y la generosidad, la decisión y la incertidumbre. También la sorpresa y la pasión [18, p. 68].

Member of the Royal Academy of Spain, scientist Jose Maria de Kossio defines the bullfighting as follows: "bullfighting fiesta which as deep roots is not only of entertainment nature, but also it is of great importance for Spanish society. So, there is no such artistic or social activity area which it doesn't have trace" [38]. The wild, the worst and the most beautiful feelings belonging to human: pain, competition, persistence, cunning, death, feeling of overcoming are gathered in corrida. Just for this reason, there is no any area of the art which enriches Spanish culture and language as this ceremony [18, p. 68]. Jose Maria de Kossio also states that the vocabulary of tauromachy that denotes the features of the bull, referring to arena, torero, corrida suertes and means of fighting runs through the veins of every Spaniard [18, p. 68]. There cannot be such conversation, festivity and assembly among friends that it passes without expressions belonging to corrida or there cannot be such newspaper or magazine which doesn't decorate its heading with these expressions. For this reason, let's look at general aspects of the field of tauromachy, more exactly, talk about the rules for the use of the vocabulary of tauromachy, its users and reasons for its use.

Terms of tauromachy consists of four levels respectively for their use in the language, that's, expressions of use: words referring to tauromachy which is a special field and only used in the bullfighting, tauromachy words with figurative meaning that can be 
used as methaphora in other fields, tauromachy words used in literature and words referring to the field of tauromachy used in the spoken language.

Words referring to tauromachy which is a special field and used only in the bullfighting: this terminology is only used by specialists and professionals acting in the field of bulfighting (torero, critics of the bullfighting etc). These words only refer to corrida.

Tauromachy lexemes with figurative meaning that can be used as a metaphor in other fields: the meaning of tauromachy terms and lexical expressions in any text belonging to the theme of the bullfighting is applied not only in this field, but in other field in a figurative meaning. For example, the word "bull" is used as the metaphor of "problem".

Tauromachy words which are used in literature: language used by writers or poets in their literary and poetic works. For poet, "bull" is a passionate creature that is inspired by woman's attraction.

Words referring to the field of tauromachy used in the spoken language: These words are far from the words of special field used in the bullfighting and terms of literary tauromachy. These are language units strengthened in the daily spoken language. Any person can speak about a topic which doesn't completely refer to this field freely using from words and expressions referring to the bullfighting.

Professor Andres Amoros gave expressions created on the basis of some terms in tauromachy and used in the spoken language in his work "Lenguaje Taurino y Sociedad". Terms which play the role of base in the creation of these expressions are as follows: bull, torero, arena, fighting tools, fight, suertes and public [20].

Linguists usually concentrate the expressions of tauromachy in four semantic group. A part of them refers to bull, majority to torero, generally, holiday and finally the fourth one to fight and death. However, we should note that there are expressions which do not refer to this semantic fields. The classification to be given will help to better understand the context of these expressions. The semantic field referring to bull covers expressions related to the features of bull and its condition 
on the arena, its activity in arena referring to torero, holiday, generally, bullfighting festive and fans, accidents and the death of a bull occurred during corrida referring to fight and death.

\begin{tabular}{|l|l|l|l|}
\hline \multicolumn{1}{|c|}{ Bull } & \multicolumn{1}{|c|}{ Torero } & \multicolumn{1}{|c|}{ Holiday } & \multicolumn{1}{|c|}{$\begin{array}{l}\text { Fight and } \\
\text { death }\end{array}$} \\
\hline $\begin{array}{l}\text { Traer a alguien } \\
\text { como a un } \\
\text { dominguillo }\end{array}$ & Tomar el olivo & Cortar orejas & $\begin{array}{l}\text { Pinchar en } \\
\text { hueso }\end{array}$ \\
\hline Como un miura & $\begin{array}{l}\text { Tener mano } \\
\text { izquierda }\end{array}$ & $\begin{array}{l}\text { Cambiar de } \\
\text { tercio }\end{array}$ & $\begin{array}{l}\text { Llegar a las } \\
\text { mulillas }\end{array}$ \\
\hline Hacer novillos & $\begin{array}{l}\text { Echarle un } \\
\text { capote a } \\
\text { alguien }\end{array}$ & & \\
\hline $\begin{array}{l}\text { Estar } \\
\text { enchiquerado }\end{array}$ & & & \\
\hline
\end{tabular}

Traer a alguien como a un dominguillo. "Dominguillo" is an entertaining game existed in the XVIII century and that has not come to this day [18, p. 128-129]. The word "dominguillo" is given as "a figure in the form of soldier put in the arena for bull to attack, scarecrow" in the dictionary of SRA (DRAE) [39]. Similar explanation is given in the book "Diccionario del arte de los toros" [25, p. 143-144] by Carlos de Torres: "cierta figura de soldado desarrapado, hecho de andrajos y embutido en paja, al cual ponen en la plaza con una lancilla o garrocha, para que el toro se cebe en él y le levante en los cuernos peloteándolo". The expression applies to "bull" as a semantic group. In the spoken language, its meaning is "to send someone to somewhere for a work" [39]. Seco explained the expression in the meaning of "a person who does his best regularly in order to do others' work". More exactly, the expression "traer a alguien como a un dominguillo" has the meaning "easily manage someone according to his wishes" [36, p. 407].

Como un miura. The expression "como una miura" in the dictionary of Spanish Royal Academy applies to the bulls of Miura farm in Seville. In comparison with other bulls, those bulls have a 
wild nature, they are more dangerous and angry [39]. Seco also gave similar definition about these bulls [36, p. 654]. The expression applies to malevolent persons with bad intentions in the spoken language.

Hacer novillos. "Novillo" means three-year-old bull in the dictionary of SRA (Spanish Royal Academy) [39]. Alberto Buitrago referred this expression to the students who didn't attend lessons and went to fight with bulls at those times in the dictionary "Diccionario de frases hechas". At present, it is compatible with the meaning "run out of school" in the spoken language [18].

Estar enchiquerado. It is used in the meaning of putting a bull in a stable in tauromachy in the dictionary of SRA. In the spoken language, it has the meaning of "arresting someone" [39].

Tomar el olivo. The origin of this expression comes from the events occurred in the lands of Cordoba and Jaen where bulls were kept mostly. When any person working in the field sees a bull or bullfighters were fighting in an outdoor, they climbed into an olive tree in order to get rid of the bull's attack. At present, in corrida, torero (bullfighter) run and hide at the back of a fence surrounding the arena in order to get rid of bull while in danger. Beltrán explains the expressions as "saltar el torero la barrera al verse perseguido por la res" [22]. Similar explanations can be seen in the dictionary of SRA and Seco "guarecerse en la barrera" [36; 39]. Carlos de Torres gives it as "saltar la barrera para salvarse de la acometida del toro" [25]. The expression refers to "torero" as a semantic group. It means "run, leave" in the spoken language in the dictionary of SRA. Seco gives the meaning of this expression as "marcharse, especialmente huyendo". It means "to be afraid of and run away from danger" in the spoken language in the dictionary of SRA. Seco gives the meaning of this expression as "marcharse, especialmente huyendo". In the everyday life, it means "to be afraid of and run away from danger" $[18,207]$.

Tener mano izquierda. This expression is referred to toreros. As mentioned above, "crutch (muleta)" is an instrument consisting of stick at the top to deceive the bull and lower its head while killing it and thick fabric at the bottom. While moving crutch, torero 
(bullfighter) who use the help of his left hand is considered to be more professional. According to the dictionary of SRA, it is used in the meaning of "having some cunning and ability in order to get out of a difficult situation" in the spoken language [39]. Cossio also explains this expression as "cunning, deceitfulness, fraudfulness". According to Seco, this expression matches the meaning of "diplomatic ability" [36].

Echar un capote. In case a bullfighter (torero) is in a difficult situation, capote is kept in front of the bull and its attention is distracted from the bullfighter (torero) in order to provide assistance. While assisting someone who is in a difficult situation, this expression is used [40].

Cortar orejas. Although this expression is not reflected in the dictionary of SRA (Spanish Royal Academy), it is said for cutting the ear of a bull by torero who has in corrida won as an award in the arena $[30$, p. 10]. The award can be one or two ears of the bull. The chairman of corrida presents the award at the request of public [25, p. 279]. If torero demonstrates brighter performance, in this case, the tail of the bull is presented to him [22, p. 164-222]. Torero who has achieved to cut two ears in corrida is removed from the arena on the shoulders of people solemnly [18, p. 100]. In terms of semantic field, this expression matches both to torero and holiday. However, taking into account the great role of public at this stage, it is considered to be appropriate to refer this expression to holiday. In the spoken language, it is used in the meaning "get of out any difficult and problem situation innocent and success obtained in the solution of a certain issue".

Cambiar de tercio. Change in tercio means transition to a new stage of the bullfighting. All three tercio that comprise the basis of corrida must finish with a single ending: bull's death. So, the sequence of these tercio during fight with great importance must be complied with. The president of corrida instructs on passing another stage in a certain time and it is realized with the accompaniment of trumpet and tambourine (percussion instrument). This expression is used while concluding one topic and passing to another one while communicating in everyday life [40]. 
Pinchar en hueso. Sometimes matador (bullfighter) cannot achieve the aim as the sword sets on the vertebral bone while swinging to kill the bull and re - tries to kill it. Followings are used in order to show that the attempt to benefit from the other out of the corrida was unsuccessful [40].

Llegar a las mulillas. The meaning of the word "mulillas" is given as "mules that carries bulls and horses died in corrida" in the dictionary of SRA [39]. Word Reference gives a similar explanation: "tiro de mulas, generalmente engalanadas que en las corridas de toros se encargan de arrastrar a los toros muertos" [42]. The expression "estar para el arrastre" used in corrida is synonymous with this expression and has the same meaning: "el arrastre" es el momento en el que el toro, ya muerto, es llevado por las mulillas "a rastras", al desolladero [18, p. 112]. Carlos Alberto Torres gave the word "mulilla" as "mules that takes bulls and horses out of the arena that have died at the stage of spear [25, p. 269]. Beltrán explained the word "mulillas" more broadly in comparison with others: "Tiro de tres mulas enganchadas en batea a un palo transversal llamado balancín, del que penden unos ganchos destinados a sujetar a la res por los cuernos y proceder a su arrastre para sacarla del ruedo. Antiguamente, salían en el paseo dos juegos de mulillas: unas, con gualdrapa roja, destinadas al arrastre de los toros; el segundo, con gualdrapas verdes, destinado a arrastrar los caballos que murieran durante la lidia; en la actualidad, sólo sale el tiro con gualdrapa roja. Las mulillas van enjaezadas con cascabeles, lazos de colores, etcétera" [22, p. 159]. Bulls are usually taken from arena to the place where their skins are peeled off [40]. Just for these reasons, the expression "llegar a las mulillas" refers to "fight and death" from semantic groups. In the spoken language, it means being late for somewhere [30, p. 16].

In terms of understanding the level of national consciousness of the people, paroemias are compounds with extremely great value. We can consider paroemias as a valuable linguoculturological source, so proverbs and sayings reflect daily lifestyle, word outlook and traditions of the people. Proverbs which have developed as a result of the historical development of language and cannot be 
divided in terms of meaning have integrated with complex phraseological system of this language which reflects old traditions.

Corrida are engraved in the consciousness of the people with the positive and negative sides. Corrida is considered an aristocratic game in the society: A la plaza, el mejor mozo de la casa. Previously, the most brave persons coming out of the people achieved the honor to be torero in this game where noblemen fight [29].

Corrida is a source of joy for people: ¡Avíate, que vas a los toros! This holiday has such a great impact on the people that people come to corrida dressing their best clothes [29].

Corrida gives pleasure and dizzies as Spanish wine: El toro y el vino, debe ser fino [43].

Corrida also expresses disappointment: ¿A dónde vas?... ¡A los toros!... ¿De dónde vienes?... De los toros. You return disappointed as the game which you went with enjoyment didn't justify your hopes [42].

Corrida expresses confusion and chaos: Aquello era una corrida de toros. It would be proper to apply this opinion mostly to the times when there were not stable rules of corrida [24].

Corrida doesn't go without fight: Bronca en el ocho. Most times, there are fights among corrida viewers when they are unsatisfied with the game or in other cases [29].

The fight seems to be easy to the public who watches the corrida from seats: Mirados desde el tendido, todos los toros son chicos; Llamar al toro desde la barrera, eso lo hace cualquiera; Desde la barrera, bien torea cualquiera, Desde la talanquera huchea al toro cualquiera; en medio del coso, es donde ha de hacerlo el valeroso; El mejor torero es el de la barrera $[21 ; 26 ; 33]$. Fight is like a play for those watching outside.

Fans early look forward for the beginning of the corrida: Eso queremos los de a caballo, que salga el toro. Corrida is a topic for conversation. When someone wishes to change any conversation, they prefer to talk about the corrida: Hablemos de toros [42].

Torero takes pride from his courage when he achieves to get rid of the horn of the bull: A cabeza pasada son las arrodilladas; A toro pasado; A cabeza pasada; Toro muerto, vaca es; A toro muerto, 
gran lanzada $[28 ; 43]$ or we see the option where the word "toro" is substituted by "moro" in the dictionary "Gran Diccionario de refranes" by Sbarbini: A moro muerto, gran lanzada. Sometimes, people come out and take pride after the danger passes and the problem is solved [41].

Torero may be incompetent and cannot cope with his job: Al mal torero, hasta los cuernos le molestan; Al torero que no hace la cruz, se lo lleva el diablo; Los toros descubren a los malos toreros $[42 ; 43]$.

If torero is skillful, the type of the bull in the arena is not important: Para un buen banderillero hay toro en todas partes. If a person is skillful, he can find a job anywhere [41].

Torero must always be vigilant: A lo mejor salta el estoque. It's better to avoid a dangerous situation than to confront it [27].

In order to be a good torero (bullfighter), first of all, one must be self-confident and expect that the bull could hurt at any time. In addition, one must continue his/ her fight in the arena gathering all his courage after the blow: El buen torero ha de ser a prueba de cuerno; El que torea al toro, tiene que aguantar la cornada; El que se mete con el toro cuidado con los cuernos; Más cornás da el hambre. Every success is gained as a result of labor [24; 29; 42].

Torero who comes across with the bull's blow has his revenge cutting it with the sword in the end: Estocada por cornada, ni el toro ni yo nos debemos nada. Eye to eye, tooth to tooth.

To be torero is not anyone's job: İrse con la capa al toro, no es para todos. Not every literate person can be Molla Panah Vagif.

A bull that gives glory to torero may also deprive him of the life. All torero who come to the art of bullfighting take this risk: Los toros dan y quitan. The one who doesn't risk, doesn't drink champagne.

Torero can be astounded not by the blow of the bull, but by the criticism of writers: Más daño suele hacer una plumada que una estocada. Words cut deeper than knives [27].

A bull should be treated carefully, as it is a source of danger: Cuídate del toro por delante, de la mula por detrás y de los frailes por todos los lados; Del mulo, por detrás; del toro, por delante; y de la 
mujer, por todas partes; Con gente de cuatro orejas, poca fiesta; Con toro toreado (jugado), mucho cuidado; A mula roma y a toro hosco no te pares de rostro; Con toro que ya han toreado, vete con mucho cuidado; ¡Te estas sentando en las astas de un toro!; ¡Cuidado que viene el toro!; De cornada de burro, no vi morir a ninguno; De cuerno, ni el tintero; De un toro, entre dos vallados, guárdate Dios o el diablo; Guarda el toro y ponte al cobro; Guárdese el cojo, y no echa la capa al toro; Antes de torear prote a rezar; Antes de torear, por las dudas rezar; Todo es toro, y corre, que te coge $[24 ; 42 ; 43]$. The farther away we stay from dangerous people and problems, the better it is, as it is not possible to put wood on the ropes.

A bull is coward and unskillful. The bull which cannot show heroism in the arena is rejected by the public and returned to the shed: $¡ A$ Al corral! It points out that something is already useless.

It is not worth to fight with an old and weak bull: Al toro por delante, y al burro por detrás, que los aguante Barrabás; Prefiero que me corra un toro antes que..... o prefiero que me corra una vaca por el cerro cuesta arriba, antes que....; Por los cuernos de un toro viejo, que no lo voy a hacer. Let me eat, sleep and rest [29].

If you sleep next to the bull, you'll also have the horn: Acuéstate con toros y amanecerás corneado. A man is known by the company he keeps.

A bull attacks quickly a limping person. It shows that all misfortunes mostly strike those who are weak. That's, the wife whose husband beats is bitten by a dog: A los cojos sigue el toro; Al más ruin toma el toro.

Baby bull is the same as the naughty bull itself: Hijo de toro matrero, siempre sale murallero. Look one's mother, marry daughter.

Sometimes, it would be a good lesson that the bull plunges its horn: El toro que me corneó a mejor prado me echó. He is wise after the event.

A bull is temporary in the arena. It presents only during the fight: El toro y el vergonzoso poco duran en el coso. Today's life is less bad [29].

A bull is a source of entertainment. When the period of corrida starts, young girls and boys tie the calf with a rope in order to have a 
good time and let it move. The calf can only run up to the length of the rope and returns back: Corre la vaguilla mientras dura la soguilla. Everyone must not go beyond the framework and cut his/her coat according to his/her cloth.

The bull enters into the arena at the age of five, and torero (bullfighter) at the age of twenty give for the first time. At these ages, they are deemed to be ready for the fight: El toro de cinco, el torero de veintecinco; El toro y el gallo, en el mes de mayo; En mayo, toro y caballo. Everything is beautiful in its time [29; 42].

Whether the bull is brave or not is known in the arena and whether the melon is tasty or not is known when it is cut: El toro y el melón, como salen son. It is also compared with woman. Whether the woman is good or not is revealed in the marriage: Tres cosas hay, que nadie sabe cómo han de ser: el melón, el toro y la mujer.

The bull is unreliable. Everything can be expected from it: Hasta el rabo, todo es toro. You cannot say that the job is completed without finishing it, because there can be unexpectedness at any time.

The bull's pursuit can give a bad result: Huyendo del toro cayó en el arroyo. Fall out of the pan into the fire.

A brave bull gains everyone's sympathy: Al toro bravo echalé vacas. People who do goodness are always respected.

A bull is wayward. It cannot be foreseen what it will do: El buey mas manso nos da la mejor patada; El toro molinero o bravo o traicionero; No es de bravo señal buena, que escarba en la arena. Events occur at a time we didn't expect.

We can expect everything from a wild bull, the difficult situation is that the coward bull sends an unexpected blow: Del agua mansa líbreme Dios, que da la brava ya me libro yo; Dios me libre de buey manso, que yo me libraré del malo. Dios me libre de los mansos; de los otros ya me libro yo. A man's hit from behind is also unexpected and as much as shattering [27; 43].

The fifth bull coming to the arena is stronger than all of them: No hay quinto malo. Most times fans leave without waiting up to the end. Farmers keep the strongest bull to the end for further revival of the game in order to prevent this. Though it is late, it is better. 
There is no torero when there is a bull and vice versa: Cuando hay toros no hay toreros, y cuando hay toreros casi nunca hay toro. When there is a horse, there is no grass and vice versa".

Good calf is born from good bull and good cow: De buena vaca y buen toro, no puede salir mal ganado; Del toro bravo, resulta el mejor novillo. Like father, like son.

Good bull brings pride to its owner: Toro veragüeño, honra a su dueño [42].

In the conclusion, it can be noted that while conducting the analysis of semantic and functional features of lexical expressions referring to Spanish tauromachy within the framework of cognitive and linguoculturological approach, we see that phraseological expressions and paroemias referring to the vocabulary of tauromachy often found in all fields of the language, both in written, spoken, and official, literary field are very comprehensive and functional in the spoken language. The similarity of meaning between expressions referring to tauromachy and expressions used in the ordinary spoken language shows how this type of art is deeply rooted in the national and moral spirit of the people. That's, lexical units used in the bullfighting have passed certain historical processes, semantic development period and different linguistic operations as a result of the culture's impact on the language and used in the spoken language and they create stylistic emotionality and expressiveness in the language. The terms of bullfighting established among culturological units in modern Spanish language are applied successfully in all genres of the language with their intense shades. In this case, we identify that the phraseological unit belonging to the vocabulary of tauromachy has gone beyond its semantic "limits" and "privatized" in different fields. First of all, it reveals that phraseological units belonging to tauromachy have "flexibility" and potential to express the desires and wishes, fear and excitement of the people in the most beautiful way: in emotional, vivid, understandable, laconic and metaphorical manner "feeling the pulse" of the modern lifestyle of the community that is the carrier of this language. 


\section{REFERENCES}

1. Balashova E.Yu. The concept of "love" in the Russian and American language consciousness / Language and national consciousness : thesis [Ponyattya "lyubov" v rosiyskiy ta amerykanskiy movniy svidomosti / Mova ta natsionalna svidomist]. Saratov, 2004. 262 p.

2. Baydili J. Proverbs [Poslovitsy]. Baku : Onder Publishing House, 2004. 264 p.

3. Bromley Yu.V., Pododolny R.G. Created by humanity [Sozdano chelovechestvom]. Moscow : Politizdat, 1984. 272 p.

4. Veysalli F.Y. Cognitive linguistics: main concepts and perspectives [Kohnityvna linhvistyka: osnovni ponyattya ta perspektyvy]. Baku : Mutarjim, 2015. $119 \mathrm{p}$.

5. Vorobiev V. V. Linguoculturology: theory and methods : textbook [Linhvokul'turolohiya: teoriya i metodyka: pidruchnyk]. Moscow : Publishing House of the Peoples' Friendship University of Russia, 1997. $331 \mathrm{p}$.

6. Vorobiev V.V. Linguoculturology : monograph [Linhvokulturolohiya]. Moscow : Publishing House of the Peoples' Friendship University of Russia, 2006. 240 p.

7. Wilhelm von Humboldt. Language and philosophy of culture [Mova ta filosofiya kultury]. Moscow : Progress, 1985. $452 \mathrm{p}$.

8. Elizarova G.V. Cultural linguistics [Kulturna linhvistyka]. Saint Petersburg: Belveder, 2000. 140 p.

9. Karasik V.I. The Language Circle: personality, concepts, discourse : monograph [Movne kolo: osobystis', ponyattya, dyskurs]. Volgograd : Peremena, 2002. 477 p.

10. Krasnykh V.V. Ethnopsycholinguistics and linguoculturology : a course of lectures [Etnopsykholohiya i linhvokul'turolohiya]. Moscow : ITDGK "Gnosis", 2002. 284 p.

11. Kourova O.I. Traditional poetic vocabulary and phraseology as a linguocultural value: a monograph [Tradytsiynyy poetychnyy slovnyk ta frazeolohiya yak linhvokulturne znachennya]. Ekaterinburg : Ural state pedagogical university, 2005. $235 \mathrm{p}$.

12. Kubryakova E.S., Demyankov V.Z., Pankkrats Yu.G., Luzina L.G. A brief dictionary of cognitive terms : dictionary [Korotkyy slovnyk kohnityvnykh terminiv]. Moscow : Moscow State University Publishing House, 1996. 245 p.

13. Luchinina E. N. Linguoculturology in the system of humanitarian knowledge [Linhvokul'turolohiya $\mathrm{v}$ systemi humanitarnykh znan]. Criticism and semiotics. Novosibirsk. 2004. Vol. 7., P. 238-243 
14. Maslova V.A. Linguoculturology [Linhvokul'turolohiya]. Moscow : Publishing Center "Academy", 2001. 208 p.

15. Popova Z.D., Sternin I.A. Semantic and cognitive analysis of language : monograph [Semantychnyy ta kohnityvnyy analiz movy]. Voronezh: Istoki, 2007. $250 \mathrm{p}$.

16. Khrolenko A.T. Basics of linguoculturology: a textbook [Osnovy linhvokulturolohiyi]. Moscow : Flint, 2004. 184 p.

17. Sheigal E.I., Buryakovskaya V.A. Linguoculturology: linguistic representation of an ethnos : textbook [Linhvokulturolohiya: movne uyavlennya pro etnos]. Volgograd : Peremena, 2002. $177 \mathrm{p}$.

18. Abella, Carlos ¡Derecho al toro! El lenguaje de los toros y su influencia en lo cotidiano. Madrid : Grupo Anaya, S. A., 1996. 276 p.

19. Amorós, Andrés Lenguaje taurino y sociedad. Madrid : Espasa Calpe, 1990. 326 p.

20. Amorós, Andrés Toros, cultura y lenguaje. Madrid : EspasaCalpe, 1999. $401 \mathrm{p}$.

21. Ballesteros J. M. Refranero taurino. Madrid : Gacetilla de la Unión de Bibliófilos Taurinos, 1958. $3 \mathrm{~h}$.

22. Beltrán Pedro Diccionario de términos taurinos. Madrid : Alderabán Ediciones, S. L., 1996. 236 p.

23. Benveniste, Émile Problemas de lingüística general. Madrid : Siglo XXI de Espana Editores, S.A., 1901. 218 p.

24. Bergua José. Refranero español. Madrid : Ediciones Ibericas, $1988.520 \mathrm{p}$.

25. Carlos de Torres, José Diccionario del arte de los toros. Madrid : Alianza Editorial, 1996. 414 p.

26. Campos J.C. y Barella A. Diccionario de refranes. Madrid : Espasa Calpe, 1993. 399 p.

27. Caudet F. Los mejores refranes españoles. Madrid : Edimat Libros, S. A., 1998. 384 p.

28. Corpas Pastor, Gloria Manual de fraseología española. Madrid : Editorial Gredos, 1997. 338 p.

29. De Ossorno M. y Serrano F. Dichos y refranes taurinos. Madrid : Editorial, 1988. 56 p.

30. Durán Luque, De Dios Juan y Pozas Manjón Fraseología, metáfora y lenguaje taurino. Granada : Método Edición, 1998. 25 p.

31. Giraldo Torres, Lina María Corridas de toros y movimiento animal: Elaboraciones psicológicas y culturales de la agresividad : trabajo de grado. Santiago de Cali, 2015. 229 p. 
32. Norbert Elias y Dunning Eric Deporte y ocio en el proceso de civilización. Nueva York : Basil Bladwell Publisher Ltd., 1986. 341 p.

33. Sbarbi, José María Diccionario de refranes, adagios, proverbios, modismos, locuciones y frases proverbiales de la lengua española. Madrid : Sucesores de Hernando, 1922. 257 p.

34. Seco Manuel Diccionario fraseológico documentado del español actual - locuciones y modismos españoles. Madrid : Aguilar lexicografía, Santillana Ediciones Generales, 2005. 961 p.

35. Tierno, Galván Desde el espectáculo a la trivialización. Madrid : Taurus, 1961. 334 p.

\section{RESOURCES}

36. DRSA - Spanish Royal Academy (2014) [online]. Dictionary of the Spanish Royal Academy. URL: http://www.rae.es/

37. Lorca, Antonio (2015). Right to the bull, the validity of the bullfighting language in everyday life [online]. El País. URL: http://cultura.elpais.com/cultura/2015/05/26/actualidad/1432629836_45319 5.html

38. Reus Boyd-Swan, Francisco The bullfighting lexicon in everyday life [online]. University of Alicante. URL: http://www.taurologia.com/imagenes/fotosdeldia/3418_estudio_el_lexico_ tauri no_en_la_vida_cotidiana.pdf

39. ${ }^{-}$Word ${ }^{-}$Reference [online]. URL: $\mathrm{http} / / / \mathrm{www}$. wordreference.com/es/translation.asp

40. URL: http://www.martinezdecarnero.com/glossword/index.ph $\mathrm{p} /$ list $/ \mathrm{Jos} \% \mathrm{C} 3 \% \mathrm{~A} 9+\mathrm{Mar} \% \mathrm{C} 3 \% \mathrm{ADa}+\mathrm{Sbarbi} \% 252 \mathrm{C} \% 0 \mathrm{D} \% 0 \mathrm{~A} \% 3 \mathrm{Cem} \% 3 \mathrm{E}$ Diccionario + de + refranes $\% 252 \mathrm{C}+$ adagios $\% 252 \mathrm{C}+$ proverbios $\% 252 \mathrm{C}+$ modis mos $\% 252 \mathrm{C}+$ locuciones $+\mathrm{y}+$ frases + proverbiales + de + la + lengua + espa $\% \mathrm{C} 3 \%$ B1ola\%3C\%252Fem\%3E\%252C+1922/2,P,A,.xhtml nos.htm

41. URL: http://www.ganaderoslidia.com/webroot/refranes_tauri

42. URL: http://toricobravoyole.blogspot.com/2017/06/refranestaurinos.html

\section{ЛИТЕРАТУРА}

1. Балашова Е.Ю. Концепт "любовь" в русском и американском языковом сознании /Язык и национальное сознание : диссертация. Саратов, 2004. 262 с. $264 \mathrm{c}$.

2. Бейдили Д. Пословицы. Баку : Ондар Нашрият, 2004. 
3. Бромлей Ю.В., Подольный Р.Г. Создано человечством. Москва : Политиздат, 1984. 272 с.

4. Вейсялли Ф.Я. Когнитивная лингвистика: основные понятия и перспективы. Баку : Мютарджим, 2015. 119 с.

5. Воробьев В.В. Лингвокультурология: теория и методы : учебное пособие. Москва : РУДН, 1997. $331 \mathrm{c.}$

6. Воробьев В.В. Лингвокультурология : монография. Москва : Издательство Российского университета дружбы народов, 2006. $240 \mathrm{c}$.

7. Гумбольдт В. Язык и философия культуры. Москва : Прогресс, 1985. 452 с.

8. Елизарова Г.В. Культурологическая лингвистика. СПб : Бельведер, 2000. 140 с.

9. Карасик В.И. Языковой круг: личность, концепты, дискурс : монография. Волгоград : Перемена, 2002. 477 с.

10. Красных В.В. Этнопсихолингвистика и лингвокультурология : курс лекций. Москва : ИТДГК "Гнозис", 2002. $284 \mathrm{c}$.

11. Коурова О.И. Традиционно-поэтическая лексика и фразеология как лингвокультурная ценность: монография. Екатеринбург: Урал. гос. пед. ун-т, 2005. 235 с.

12. Кубрякова Е.С., Демьянков В.3, Панкрац Ю.Г, Лузина Л.Г Краткий словарь когнитивных терминов : словарь. Москва : Издательство Московского государственного университета, 1996. $245 \mathrm{c}$.

13. Лучинина Е.Н. Лингвокультурология в системе гуманитарного знания : статья. Новосибирск : Критика и семиотика, 2004. Вып. 7., С. 238-243

14. Маслова В.А. Лингвокультурология: Учеб. пособие для студ. высш. учеб, заведений. Москва : Издательский центр "Академия", 2001. 208 с.

15. Попова З.Д., Стернин И.А. Семантико-когнитивный анализ языка : монография. Воронеж : Истоки, 2007. 250 с.

16. Хроленко А.Т. Основы лингвокультурологии : учебное пособие. Москва : Флинта, 2004. 184 с.

17. Шейгал Е.И., Буряковская В.А. Лингвокультурология: языковая репрезентация этноса : Учеб.-метод. пособие. Волгоград : Перемена, 2002. 177 с.

18. Abella, Carlos ¡Derecho al toro! El lenguaje de los toros y su influencia en lo cotidiano. Madrid : Grupo Anaya, S. A., 1996. 276 p. 
19. Amorós, Andrés Lenguaje taurino y sociedad. Madrid : Espasa Calpe, 1990. 326 p.

20. Amorós, Andrés Toros, cultura y lenguaje. Madrid : EspasaCalpe, 1999. $401 \mathrm{p}$.

21. Ballesteros J. M. Refranero taurino. Madrid : Gacetilla de la Unión de Bibliófilos Taurinos, 1958. $3 \mathrm{~h}$.

22. Beltrán Pedro Diccionario de términos taurinos. Madrid : Alderabán Ediciones, S. L., 1996. 236 p.

23. Benveniste, Émile Problemas de lingüística general. Madrid : Siglo XXI de Espana Editores, S.A., 1901. 218 p.

24. Bergua José. Refranero español. Madrid : Ediciones Ibericas, $1988.520 \mathrm{p}$.

25. Carlos de Torres, José Diccionario del arte de los toros. Madrid : Alianza Editorial, 1996. 414 p.

26. Campos J.C. y Barella A. Diccionario de refranes. Madrid: Espasa Calpe, 1993. 399 p.

27. Caudet F. Los mejores refranes españoles. Madrid : Edimat Libros, S. A., 1998. 384 p.

28. Corpas Pastor, Gloria Manual de fraseología española. Madrid : Editorial Gredos, 1997. 338 p.

29. De Ossorno M. y Serrano F. Dichos y refranes taurinos. Madrid : Editorial, 1988. 56 p.

30. Durán Luque, De Dios Juan y Pozas Manjón Fraseología, metáfora y lenguaje taurino. Granada : Método Edición, 1998. 25 p.

31. Giraldo Torres, Lina María Corridas de toros y movimiento animal: Elaboraciones psicológicas y culturales de la agresividad : trabajo de grado. Santiago de Cali, 2015. 229 p.

32. Norbert Elias y Dunning Eric Deporte y ocio en el proceso de civilización. Nueva York : Basil Bladwell Publisher Ltd., 1986. 341 p.

33. Sbarbi, José María Diccionario de refranes, adagios, proverbios, modismos, locuciones y frases proverbiales de la lengua española. Madrid : Sucesores de Hernando, 1922. 257 p.

34. Seco Manuel Diccionario fraseológico documentado del español actual - locuciones y modismos españoles. Madrid : Aguilar lexicografía, Santillana Ediciones Generales, 2005. 961 p.

35. Tierno, Galván Desde el espectáculo a la trivialización. Madrid : Taurus, 1961. 334 p. 


\section{ИСТОЧНИКИ}

36. СИКА - Испанская Королевская академия (2014) [онлайн]. Словарь Испанской Королевской Академии. URL: http://www.rae.es/

37. Лорка Антонио (2015). Право на быка, действительность корриды в повседневной жизни [онлайн]. Эл Паис. URL: http://cultura.elpais.com/cultura/2015/05/26/actualidad/1432629836 453195.html

38. Реус Бойд-Сван, Франциско Лексика корриды в повседневной жизни [онлайн]. Университет Аликанте. URL: http://www.taurologia.com/imagenes/fotosdeldia/3418_estudio_el_lexico_ tauri no en la vida cotidiana.pdf

39. - Ворд Референс [онлайн]. URL: $\mathrm{http} / / / \mathrm{www}$. wordreference.com/es/translation.asp

40. URL: http://www.martinezdecarnero.com/glossword/index.ph $\mathrm{p} /$ list $/ \mathrm{Jos} \% \mathrm{C} 3 \% \mathrm{~A} 9+\mathrm{Mar} \% \mathrm{C} 3 \% \mathrm{ADa}+\mathrm{Sbarbi} \% 252 \mathrm{C} \% 0 \mathrm{D} \% 0 \mathrm{~A} \% 3 \mathrm{Cem} \% 3 \mathrm{E}$ Diccionario + de + refranes $\% 252 \mathrm{C}+$ adagios $\% 252 \mathrm{C}+$ proverbios $\% 252 \mathrm{C}+$ modis mos $\% 252 \mathrm{C}+$ locuciones $+\mathrm{y}+$ frases + proverbiales $+\mathrm{de}+$ la + lengua + espa $\% \mathrm{C} 3 \%$ B1ola $\% 3 \mathrm{C} \% 252 \mathrm{Fem} \% 3 \mathrm{E} \% 252 \mathrm{C}+1922 / 2, \mathrm{P}, \mathrm{A}, \mathrm{xhtml}$

41. URL: http://www.ganaderoslidia.com/webroot/refranes tauri nos.htm

42. URL: http://toricobravoyole.blogspot.com/2017/06/refranestaurinos.html

$$
\begin{aligned}
& \text { Дата надходження до редакції - 29.10.2018 p. } \\
& \text { Дата затвердження редакцісю - 23.11.2018 р. }
\end{aligned}
$$

